\title{
Training newly appointed reference librarians
}

\author{
By Mariol R. Wogaman \\ Assistant Head of Reference Services \\ Oregon State University
}

\section{Adequate orientation pays off in many ways.}

A survey by Karen Y. Stabler of newly appointed academic reference librarians revealed that they felt a need for well-planned training programs. Respondents reported having received training for periods ranging from one day to three months. McGill University's McLennan Library has a comprehensive training program for reference desk staff which extends over three months and is well documented (ED 175486), but that does not seem to be typical. At the Oregon State University Library, reference supervisors are convinced of the importance of adequate training. Since 1981 many of the reference librarians hire d by the library have undergone a structured training program, lasting three to four weeks, that introduced them both to the reference department and to other departments within the library. The OSU Reference Division currently has 14 reference librarians who share general reference duties as well as specific subject responsibilities for in-depth reference, collection development, and bibliographic instruction. Each of the librarians participates in training new members of the professional staff, meeting with them for an hour or two (or longer if necessary) to show them reference sources and share information about the type of reference questions received and the clientele served. Three purposes are served by thus sharing the responsibility for training: the subject librarians are able to share their expertise in providing reference service in their subject areas; each new librarian spends one-on-one time with each other librarian in the department, giving them an opportunity to get acquainted; the primary subject areas in which we provide reference assistance are all covered. New librarians are given tours of other major units of the library. Hour-long sessions don't allow for in-depth discussions of the operations of these departments, but do provide time for introductions to the staff and brief overviews of the functions of the departments. The third component of training is initiation into service at the reference desk. Ideally, new librarians are introduced to reference service gradually. After they have been in training for two or three days, they are scheduled to observe at the reference desk, using the time to browse in the reference area, listen to the questions being asked and the answers given, and ask questions of the librarians on duty. After six to eight sessions like this, they are scheduled to work at the reference desk with one or two experienced librarians. An attempt has been made to schedule new staff to work at the reference desk with different librarians throughout the week, so that the new people will have an opportunity to learn from staff with different subject backgrounds. Although we prefer for new librarians to work at least two weeks with two other librarians on the reference desk before they are scheduled to work regular shifts with only one other librarian, we sometimes have to compromise on this, depending on how urgently help is needed at the reference desk and whether classes are in session when new librarians begin work.

\section{Developing a schedule}

As soon as the starting date of the new librarian is known, the coordinator of reference training 
begins developing a schedule. The list of approximately 35 areas and topics to be covered must be coordinated with library meetings, holidays, and the schedules of trainers. The coordinator roughs out a schedule, then contacts each staff person to get confirmation of willingness to assist in the training and availability at the time scheduled. The coordinator has always found staff in both the reference department and other divisions to be very willing to participate. After times and dates of training sessions are confirmed, a final schedule covering three or four weeks is prepared to give to the new librarian on the first day of work. When we first devised this training program, we made the mistake of not allowing sufficient free time for the new librarian to browse the reference stacks and absorb the information that was beingpresented. Experience has taught us that it is better to spread the training over a longer period of time, whenever possible, allowing the new librarian free time each day to review and digest information. A training program like this requires the cooperation of many people; about 23 library staff members participated in training the latest group of new reference librarians. Unforeseen conflicts can require training schedules to be revised. Since this could result in inadvertent omissions, the training needs to be monitored so that the coordinator is sure that all areas are covered.

\section{Evaluation}

The program just described has been used for 13 reference librarians, ranging from new graduates of library school to a former public library administrator who was entering academic librarianship. No formal evaluation of the program has been undertaken, but conversations between the training coordinator and the most recent trainees indicate that the training was helpful. We know that we need better training materials, especially a manual covering current policies and procedures. Brief weekly meetings of the trainees with the coordinator have provided opportunities for mutual feedback. The trainees have reiterated their need for up-to-date, written policies and procedures and adequate free time to observe at the reference desk and to learn the reference collection. The importance of thorough orientation for new employees cannot be overstated. Even experienced librarians who possess the skills and knowledge necessary for reference service need an orientation to the new work situation, introduction to the staff and the physical environment, and an understanding of the wider context in which they will be working and the clientele they will be serving. Adequate planning and time spent in the initial phase of a new employee's service will be repaid through increased quantity and quality of work, less need for close supervision, and higher job satisfaction.

\section{New Publications from ACRL}

ALA Order Dept. 1-800-545-2433, 50 E. Huron St, Chicago, IL 60611-2795

\section{VACRL/Historically Black}

Colleges \& Universities

Library Statistics, 1988-89

$\$ 35.95 /$ ACRL member $\$ 25.95$

ISBN 0-8389-7547-X

Genre Terms: A Thesaurus for Use in

Rare Book and Special Collections

Cataloguing (2nd ed.)

\$19.95/ACRL member $\$ 16.95$

ISBN 0-8389-7516-X

7 College \& Research Libraries and

College \& Research Libraries News, Index for Volumes 41-50 (1980-1989)

$\$ 29.95 / A C R L$ member $\$ 25.95$

ISBN 0-8389-7487-2
VRead This First: An Owner's

Guide to the New Model

Statement of Objectives for

Academic Bibliographic

Instruction

\$17.95/ACRL member \$14.95

ISBN 0-8389-7548-8

Recruiting the Academic Library

Director (ACRL) and The Search

Committee Handbook (AAHE)

\$16.95/ACRL member $\$ 13.95$

ISBN (set) 0-8389-7484-8 